\title{
Barbara Kulesza-Gulczyńska
}

\section{Czytanie gier, gra w czytanie}

\author{
$\begin{array}{llllllll} & k & r & y & t & y & k & i\end{array}$ \\ P i otr Kubiński, Gry wideo. \\ Zarys poetyki, Kraków 2016.
}

Kluczowa funkcja, jaką pełnią we współczesnej kulturze gry wideo, dostrzegana jest coraz częściej przez badaczy zjawiska. Zwraca się uwagę na fakt, że poza oczywistą funkcją ludyczną i rozrywkową, realizują one także inne zadania i mają istotny wpływ na pozostałe dziedziny dzisiejszej sztuki. „Młodość” zjawiska (pierwsze gry komputerowe przeznaczone do powszechnego użytku powstawały w latach siedemdziesiątych XX wieku) i jego gwałtowny rozwój, ściśle związany z rozwojem nowych technologii, czynią z niego niezwykle interesujący, choć trudny obiekt badawczy. Mimo że ten stan rzeczy w ostatnich latach ulega istotnym zmianom, ze względu na coraz bardziej dynamiczną działalność badaczy zjawisk z zakresu nowych mediów, pewną trudność dla badaczy gier wideo wciąż stanowi konieczność uzasadnienia istotności fenomenu należącego, w powszechnej świadomości, do dziedziny „niskich rozrywek”, obarczonego negatywnymi konotacjami (problematyka przemocy, uzależnienia), w badaniach naukowych. Dodatkowymi, być może istotniejszymi jeszcze ze względów metodologicznych, utrudnieniami wydają się intensywny i trudny do uchwycenia rozwój technologiczny (robocze kategorie wypracowane do opisu gier z początku XXI wieku nierzadko okazują się niewystarczające do opisu gier tworzonych współcześnie), a także - konieczność wypracowania odpowiednich narzędzi i kategorii opisu zjawiska, wymykającego się, zarówno pod względem pojęciowym, jak i treściowym, aparatowi pojęciowemu i teoriom z zakresu istniejących już dziedzin.

Świadomość tego problemu była jedną z podstaw game studies czy też ludologii - ich podstawowym celem miało bowiem stać się uniezależnienie dyskursu badania gier od kategorii wykorzystywanych do opisu innych zjawisk i wypracowanie odpowiedniego aparatu metodologicznego, pozwalającego na uchwycenie specyfiki zjawiska w kategoriach dla niego wyłącznie właściwych. Powstały tu spór między ludologami (zwolennikami poszukiwania nowych narzędzi i kategorii badawczych w opisie gier) a narratologami (uznającymi, że gry warto badać za pomocą tradycyjnych kategorii pozwalających na badanie tekstów/narracji i że jest to metodologia wystarczająca) został szeroko opisany w literaturze przedmiotu ${ }^{1}$. Piotr Kubiński już we wstępie do swojego zarysu poetyki gier wideo ${ }^{2}$ podkreśla jednak, rzucający się w oczy, pozorny charakter tego sporu. Przyjmując szeroką perspektywę badawczą i przyznając się do czerpania z wielu metod i dziedzin nauki, autor publi-

\footnotetext{
1 Patrz choćby: G. Frasca, Ludology meets narratology. Similitude and differences between (video)games and narrative, <http://www.ludology.org/articles/ludology.html> [dostepp: 28.01.2017]; A. Surdyk, Status naukowy ludologii. Przyczynek do dyskusji, „Homo Ludens” 2009, nr 1, s. 223243.

2 P. Kubiński, Gry wideo. Zarys poetyki, Kraków 2016.
} 
kacji Gry wideo. Zarys poetyki słusznie twierdzi, że złożoność i niepowtarzalność zjawiska gier wideo wymaga zastosowania wielu różnorodnych narzędzi i rozwiązań, w zależności od aspektu zjawiska, na którym zamierzamy się koncentrować. Tytułowa „poetyka” nie powinna tu sugerować ograniczenia się do stosowania wyłącznie tradycyjnych narzędzi literaturoznawczych. Kubiński przywołuje nowoczesne rozumienie poetyki jako narzędzia odpowiedniego do badania różnorodnych form tekstowości, równocześnie przyjmując bardzo szerokie rozumienie tekstu, pozwalające włączyć w jego obręb także kategorie nieznajdujące się w dziedzinie zainteresowań klasycznego literaturoznawstwa.

Warto już w tym miejscu zauważyć, że Kubiński, analizując różnorodne elementy poetyki gier wideo, doskonale balansuje, akcentując z jednej strony pokrewieństwo stosowanych w grach rozwiązań z zabiegami wykorzystywanymi w innych dziedzinach sztuki (kinie, literaturze i malarstwie), z drugiej - ukazując istotne różnice, świadczące o niepowtarzalności opisywanych chwytów. Równowaga ta, podobnie jak otwarte czerpanie z różnorodnych teorii z dziedziny literaturoznawstwa i nie tylko, połączone z wiedzą z zakresu technologii informacyjnych, pozwala dostrzec znaczące starania zmierzające do skonstruowania narzędzi opisu dających możliwość mówienia o grach wideo, istotnym elemencie współczesnej kultury, jako o zjawisku z jednej strony - niepowtarzalnym, a z drugiej - zakorzenionym w tradycji i czerpiącym z niej na wiele różnych sposobów. Podkreślenie nie tylko ludycznych, ale także artystycznych walorów analizowanych gier jest również istotnym spostrzeżeniem sytuującym to zjawisko w centrum współczesnej kultury.

Swoją propozycję narzędzi opisu gier wideo Kubiński rozpoczyna od omówienia zjawiska immersji, którą, za wieloma badaczami, uznaje za jeden z konstytutywnych elementów poetyki gier wideo. Operacjonalizując wykorzystywane przez badaczy gier pojęcia i podejmując próbę rozstrzygnięcia terminologicznych wątpliwości (różnice między pojęciami teleobecności, immersji, inkorporacji, a także różnice w definiowaniu immersji jako takiej), Kubiński decyduje się na zdefiniowanie tego zjawiska jako „wrażenia niezmediatyzowanego uczestnictwa, bezpośredniej obecności w cyfrowej przestrzeni generowa- nej komputerowo”3. Autor podkreśla istotność „zawłaszczenia” gracza przez dzieło o charakterze immersyjnym, fakt, że świat gry pochłania użytkownika, „wyrywając” go z pozacyfrowej rzeczywistości. Kubiński, zgodnie z przyjętą przez siebie strategią balansowania między podobnym a różniącym, nie stawia mocnej tezy, jakoby immersja miała ograniczać się wyłącznie do dziedziny gier wideo. Przywołuje uwagi dotyczące immersyjnych właściwości innych dziedzin sztuki, wrażenia pochłonięcia czy to przez tekst literacki, czy przez dzieło filmowe, poszukując równocześnie tego, co potraktować można jako charakterystyczne wyłącznie dla gier wideo, by uniknąć rozmycia pojęcia. W znaczącym stopniu pozwala na to wyróżnienie i szczegółowe omówienie czynników kształtujących poczucie zanurzenia w świecie w grach wideo, do których należą: wrażenie niezmediatyzowania, iluzja bezpośredniego uczestnictwa w grze, elementy ergodyczne, kinetyczny wymiar działalności gracza oraz niezawodność wykorzystywanych technologii. Istotne jest tu spostrzeżenie, że do osiągnięcia wrażenia immersji w przypadku gry komputerowej nie jest niezbędna próba iluzyjnego oddania rzeczywistości w stosunku 1:1, które w coraz większym stopniu mogłaby umożliwiać rozwinięta technologia. Gry tekstowe oparte wyłącznie na wymianie wiadomości za pośrednictwem internetowej platformy czy najprostsze gry zręcznościowe mogą mieć, zgodnie z tym rozumowaniem, równie wysoki potencjał immersyjny jak rozbudowane graficznie i technologicznie, złożone symulacje alternatywnych światów.

Elementem wywodu, który sam autor uznaje za szczególnie istotny, a i z perspektywy czytelnika zainteresowanego badaniem gier wydaje się on w znaczącym stopniu wzbogacający stan badań, jest podjęta w kolejnym rozdziale refleksja nad zjawiskiem „emersji”, którą Kubiński rozumie jako zjawisko przeciwstawne do immersji, „wytrącające” użytkownika z poczucia zanurzenia w alternatywnej rzeczywistości, demaskujące poniekąd iluzyjne dążenia gry. Od momentu wprowadzenia tej kategorii wszelkie kolejne opisywane zjawiska rysują się gdzieś w polu napięcia pomiędzy immersją a emersją, pomiędzy dążeniem do jak najgłębszego wciągnięcia użytkownika w kreowany świat a nieświadomym lub, co

\footnotetext{
${ }^{3}$ Tamże, s. 52.
} 
niewątpliwie bardziej interesujące, świadomym „wybijaniem” go i „wynurzaniem”.

Wydawać by się mogło, że do elementów emersyjnych w grze komputerowej należeć będą przede wszystkim błędy i uchybienia o charakterze technicznym czy systemowym, stanowiące ograniczenia technologiczne. Autor szeroko omawia tu problemy związane z fasadowością stworzonej na potrzeby gry scenografii, która w określonych okolicznościach może, przypadkiem, wyjść na jaw, nieuzasadnione fabułą gry deformacje postaci lub elementów świata diegetycznego lub choćby dobrze znane sytuacje, w których bohater wchodzi na „niewidzialną ścianę”, docierając do granicy mapy, stanowiącej „koniec diegetycznego świata”. Zjawiska tego typu Kubiński określa mianem technicznej deziluzji, słusznie zauważając, że mogą one mieć nie tylko charakter błędów czy technicznych niedoskonałości, ale również, co znacznie ciekawsze, mogą służyć osiągnięciu celów artystycznych. Autor wspomina interesujący przykład gry Batman. Arkham Asylum, w której pozorny błąd maszyny (charakterystyczne pasy na ekranie, którym towarzyszą odpowiednie dźwięki sugerujące usterkę sprzętową, a także pozorne wznowienie gry po krótkiej chwili) stanowi element fabuły, ilustrujący odczucia zatrutego toksynami głównego bohatera, doświadczajacego halucynacji. Efekt taki niewątpliwie wywołuje zdziwienie i „wytrącenie” z rytmu (szczególnie w przypadku, gdy gracz obawia się, że postęp gry, który udało mu się osiągnąć, zostanie ze względu na usterkę bezpowrotnie utracony), przypomina więc (podobieństwo to dostrzega Kubiński) efekt „udziwnienia” - wprowadzoną przez

\footnotetext{
${ }^{4}$ Zastanawiajace $w$ tym przypadku może być, czy podobny efekt emersyjny może mieć na przykład błąd drukarski lub usterka językowa dostrzeżone przez czytelnika w trakcie pasjonującej lektury (autor jako kontekst wymienia błędy filmowe, takie jak pojawienie się na planie obiektów nieprzynależących do świata przedstawionego, a do świata realnego, jak kubki kawy czy zegarki w filmach historycznych lub fantasy). Napięcie między „immersją" a „emersją" zarysowuje się tu w sposób bardzo frapujący stopień „immersji” może bowiem ograniczyć skuteczność oddziaływania czynników emersyjnych (podążając za fabułą, nietrudno przeoczyć interpunkcyjną usterkę, a i śledzenie błędów w filmach nierzadko wymaga ogromnej uwagi i koncentracji na aspektach technicznych, zamiast na aspektach fabularnych) - w przypadku gier wideo natomiast „przeoczenie” czynników emersyjnych nie zawsze jest w ogóle możliwe - czasem uniemożliwiają one bowiem po prostu śledzenie fabuły czy kontynuację gry.
}

Wiktora Szkłowskiego, jedną z kluczowych kategorii formalizmu rosyjskiego. Daje on szerokie pole do interpretacji, nawet jeżeli stanowi element przekazu, który sam Kubińsk traktuje jako pierwotnie popularny i ludyczny. Ma potencjał metamedialny - interesujące jest bowiem, że reakcje umysłu bohatera, poddanego działaniu toksyny, przypominają reakcje zepsutej maszyny - może to sugerować pewien stopień cyborgizacji bohatera.

Do opisu innej kategorii zjawisk emersyjnych Kubiński wykorzystuje z kolei literaturoznawczą kategorię ironii, czy raczej dystansu ironicznego, przywołując koncepcję Zofii Mitosek. Autor zarysowuje sytuację, w której, w ramach fabuły gry, dochodzi do wytworzenia się dystansu wobec tekstu jako takiego, ironicznego ukazania jego tekstowego charakteru, poprzez odniesienie do pozatekstowej rzeczywistości. Tu Kubiński przywołuje przykład polskiej gry Wiedźmin, w której aluzje do popularnych piosenek (Celiny Stanisława Staszewskiego), sytuacji politycznej (przywołanie Prawa i Sprawiedliwości) oraz... historii filozofii (nazwiska Sørena Kiergegaarda i Martina Heideggera) jako hasła w języku elfów, nie będąc oderwane od toku fabuły gry, powodują swoiste „wyjście” ze świata diegetycznego do świata realnego. Aluzje te nie mogą być bowiem czytelne dla bohaterów (choć przecież wypowiadane są poniekąd ich ustami), są natomiast czytelne dla gracza. Jak zauważa Kubiński, dochodzi tu do swoistej przemiany modelu komunikacji, pojawia się bowiem jakiś rodzaj nadawcy, który nie jest bohaterem i ma świadomość zbliżoną do świadomości gracza, co pozwala mu wkładać w usta bohaterów gry komunikaty, wywołujące efekt zaskoczenia czy efekt humorystyczny ${ }^{5}$.

Kolejnym wyróżnionym przez Kubińskiego środkiem kształtującym emersję jest „burzenie czwartej ściany” (wykorzystanie tego terminu, który wydaje się w tym kontekście bardzo trafny, po raz kolejny pokazuje, że budując warsztat badawczy, autor nieustannie odwołuje się do narzędzi i kategorii tradycyjnych, wpisując gry

\footnotetext{
${ }^{5}$ Warto tu wspomnieć, że podobne (niejednokrotnie znacznie bardziej wyrafinowane) zabiegi stosował w swoich książkach o Wiedźminie autor tej postaci, Andrzej Sapkowski. Odwołania do rzeczywistości absolutnie zewnętrznej wobec świata przedstawionego tu również nie pełniły wyłącznie funkcji interesujących, nierzadko niełatwych do wytropienia, aluzji literackich, ale także zdawały się tworzyć ów „ironiczny dystans”.
} 
wideo w pewne kulturowo-medialne kontinuum). To sytuacja, w której bohater gry zwraca się bezpośrednio do gracza na przykład po to, by wytłumaczyć mu reguły gry lub wywołać efekt humorystyczny. Znów dochodzi tu do swoistego napięcia na linii immersja - emersja, które ukazać można na niewymienionym przez Kubińskiego przykładzie gier opartych na serii książek J.K. Rowling o Harrym Potterze. W grach tych instrukcji co do sposobu wykonywania zaklęć udzielają nauczyciele podczas lekcji, na które należy się udać, by ukończyć określony etap gry (efekt immersyjny - zanurzamy się w tworzonym świecie jako uczniowie Hogwartu). Równocześnie jednak, nauczyciele ci, zamiast instruować gracza co do sposobu poruszania różdżką, jak czynili to w książkowym oryginale, odnoszą się do sposobów korzystania z narzędzi dostępnych graczowi (np. wciśnij przycisk myszy), co ma charakter emersyjny, który wydaje się jednak do pewnego stopnia zamaskowany. Gdzie indziej na tej linii znajdują się sytuacje, w których zwrot do użytkownika/gracza ma charakter „mrugnięcia okiem” i ma wywołać efekt komiczny lub efekt zaskoczenia czy gry z konwencją (wspomniane przez Kubińskiego zachowanie Deadpoola w grze Marvel vs. Capcom).

Autor, pisząc o efektach emersyjnych, przywołuje też zabieg gry sytuacją narracyjną i wiarygodnością narratora - w opisywanym przykładzie gry Call of Juarez: Gunslinger, w sytuacji, kiedy bohater gry jest również jej narratorem, użytkownik dostrzega, że opowieść ma wpływ na przedstawianą sytuację - wypowiedzi narratora nabierają charakteru performatywnego, realnie zmieniając jego położenie. Wprowadzenie kategorii narratora nie-

wiarygodnego jest tu kolejnym ukłonem w stronę klasycznych teorii literaturoznawczych, doskonale jednak wpisującym się również w poetykę gier wideo.

Bardzo istotnym wprowadzonym tu pojęciem, które pozwala na uchwycenie specyfiki medium, przy równoczesnym uwzględnieniu tradycyjnych kategorii, jest próba palimpsestowa, którą Kubiński określa sytuację „nakładania" się na siebie różnych przebiegów fabuły, wynikającą z możliwości zapisania stanu gry (przewidywanej przez większość złożonych gier przygodowych czy platformowych) i przejściu pewnego etapu po raz kolejny. Jeśli postać zginie w starciu ze zbyt silnym przeciwnikiem, gracz uruchomi grę po raz kolejny w punkcie kontrolnym i, mając świadomość nadchodzącego starcia, lepiej się do niego przygotuje, zmieniając tok przebiegu akcji. Tego typu operacje mogą również pozwalać na równoczesną eksplorację wielu wariantów fabuły (w momencie, gdy na jej rozwój wpływają określone decyzje gracza). Daje to niepowtarzalny rezultat narracyjny, w którym przebieg narracji powstającej „na wierzchu” pozostaje niejako uzależniony od tych zapisanych „pod spodem”, będąc równocześnie sygnałem emersyjnym, uwypuklającym charakterystyczne cechy medium, naruszającym więc jego „przezroczystość” i wrażenie niezmediatyzowania.

Po szczególnie interesującym rozdziale dotyczącym emersji Kubiński wykorzystuje nadal zarysowane przez siebie napięcia na linii immersja - emersja, charakteryzując rodzaje graficznych interfejsów użytkownika wykorzystywanych w grach komputerowych. Autor proponuje własną klasyfikację tego typu interfejsów, dzieląc je według kryterium diegetyczności i przestrzenności, a także subkryteriów diegetyczności komunikatu, filtru kontekstowego i ikoniczności dynamicznej. Ze względu na rozległość materiału badawczego i ciągły rozwój technologiczny trudno z całą pewnością stwierdzić, czy klasyfikacja ta jest wyczerpująca, każda z wymienionych kategorii została tu jednak zilustrowana odpowiednimi przykładami i opisana w sposób ukazujący operacyjną użyteczność wspomnianego podziału. Autor dzieli interfejsy na: nakładki, metareprezentacje, filtry sytuacyjne, interfejsy przestrzenne, komunikaty diegetyczne, semeiony i metainterfejsy. Pokazuje on jednocześnie, że interfejs jako taki siłą rzeczy będzie miał charakter emersyjny, jest bowiem narzędziem umożliwiającym komunikację człowieka z maszyną, dostarczającym informacji dotyczących świata diegetycznego, w wielu przypadkach (szczególnie jeśli chodzi o nakładki) funkcjonując niejako „obok” rzeczywistości gry, pozostając w ścisłym związku z nią. Efekt emersji łagodzą na przykład przede wszystkim metainterfejsy - to zjawisko niezmiernie interesujące, wskazujące na wielopoziomowe relacje metatekstualne w obrębie gier wideo. Metainterfejsy są bowiem interfejsami funkcjonującymi w świecie gry (czyli narzędziami, pozwalającymi bohaterowi na skomunikowanie się z urządzeniem, którego używa, a równocześnie, umożliwiającymi użytkownikowi zdobywanie informacji o świecie diegetycznym). 
Jeśli bohater (przywołany jako przykład przez Kubińskiego) jest cyborgiem, używającym specjalnych soczewek, dostarczających mu informacji na temat dostrzeganych obiektów (co istotne - zdobywa je dopiero na pewnym etapie gry), informacje te docierają zarówno do bohatera, jak i do użytkownika, stając się swoistym interfejsem „piętrowym”. Prowadzi to nie tylko do zmniejszenia efektu emersyjności - ma także efekt estetyczny, artystyczny i daje ogromny potencjał interpretacyjny.

Kubiński charakteryzuje również stosowane przez twórców gier strategie redukcji emersyjności interfejsów, takie jak minimalizacja (ograniczenie elementów interfejsu do minimum, tak by immersja była zaburzona w najmniejszym możliwym stopniu), stylizacja (elementy interfejsu są stylizowane na część świata gry, choć go nie stanowią - ciekawym przykładem jest tu stylizacja interfejsu gry Fifa 15 na telewizyjną transmisję meczu pokazuje to wielopiętrowe i skomplikowane relacje między mediami), diegetyzacja (włączanie interfejsu w świat diegetyczny), konfiguracyjność (możliwość ustawienia interfejsu przez użytkownika) czy tematyzacja (wykorzystanie interfejsu jako istotnego elementu rozgrywki).

Użyteczności dokonanych przez autora rozróżnień i klasyfikacji wydają się dowodzić drobiazgowe analizy i interpretacje mnogości przywoływanych przykładów. Kubiński sięga po rozmaite gatunki gier (gry przygodowe, „bijatyki”, gry platformowe, symulatory, strzelanki), kierowane do różnorodnych adresatów, których autorzy, siłą rzeczy, sięgali po bardzo różnorodne artystyczne rozwiązania. Rozbudowana egzemplifikacja, poza niezaprzeczalnym atutem w zakresie dowodzenia stosowności zaproponowanych rozstrzygnięć, daje również czytelnikowi możliwość zapoznania się z wieloma zjawiskami z zakresu kultury gier wideo, z którymi mógł nie mieć dotychczas styczności (jest to szczególnie cenne w obliczu ogromu materiału badawczego), ale także może stanowić zachętę do „podstawienia” do proponowanych kategorii dobrze sobie znanych gier i „przetestowania" ich funkcjonalności.

W ostatnim rozdziale Kubiński zarysowuje wybrane przykłady wpływu poetyki gier wideo na inne zjawiska i teksty kultury. Wychodząc od analizy dzieł z zakresu literatury grywalnej, poprzez krótkie opisanie fenomenu grywalizacji, do drobiazgowej analizy dwóch przykładów gier z gatunku zaangażowanych. Niezmiernie istotne wydaje się tu wprost zasygnalizowane przez autora konieczne ograniczenie zakresu analizy i opisu do niektórych, szczególnie być może interesujących lub najlepiej znanych autorowi fenomenów. Biorąc pod uwage drobiazgowość analizy konkretnych przykładów i interesujące wnioski, po lekturze ostatniego rozdziału książki odczuwa się pewien niedosyt, jednak zdecydowanie się na zarysowanie i otwarcie kolejnych płaszczyzn naukowej refleksji w obszarze gier wydaje się zabiegiem wartościowym.

Kubiński jako przykłady literatury grywalnej analizuje utwory Nokianor Parra oraz Laberinto Borgiano B.R. Moreno-Ortiza. Klasyczne utwory literackie twórca łączy tu z niemal równie klasycznymi prostymi grami zręcznościowymi: grą Snake na telefony komórkowe typu Nokia oraz Pacmanem. W pierwszym przypadku tekst rozwija się wraz z postępami, jakie w grze czyni użytkownik (wąż, jak w oryginalnej grze, zjada kulki, budując swoje ciało z liter tworzących prezentowany utwór), w drugim - Pacman zjada litery $a$, natomiast oryginalny utwór Borgesa buduje ściany labiryntu. Analiza tych grywalnych utworów pozwala na wydobycie szczególnych znaczeń zarysowujących się w zderzeniu fenomenów z dziedziny literatury i gier, a także ich potencjału w zakresie specyficznych efektów artystycznych (warto tu, za Kubińskim, podkreślić, że sposób czytania i interpretowania literackich utworów grywalnych diametralnie różni się od tradycyjnej linearnej lektury, nie unieważnia jej jednak, a tylko wprowadza pewien frapujący wariant).

Dalej, analizując zagadnienie grywalizacji, Kubiński opisuje funkcjonowanie popularnej platformy e-learningowej Moodle, wykorzystującej systemy punktacji i rankingów w programie mającym ułatwiać dystrybucję materiałów akademickich i wspierać proces studiowania. Kwestia grywalizacji zostaje tu jednak wyłącznie zasygnalizowana, czego świadom jest sam autor, odwołując się szeroko do literatury przedmiotu i zachęcając do dalszych dociekań w tym zakresie.

Drobiazgowo analizuje natomiast Kubiński wybrane przykłady gier zaangażowanych, czyli takich, w których 
funkcja ludyczna podporządkowana zostaje niejako funkcji publicystycznej. Poddając refleksji dwie proste internetowe gry (Raid Gaza! oraz Save Israel) powstałe w związku z wieloletnim konfliktem izraelsko-palestyńskim w Strefie Gazy, Kubiński uwypukla szczególne właściwości tego typu gier, czyniące je istotnym narzędziem w zakresie oddziaływania społecznego. Ironia, będąca cechą konstytutywną szczególnie pierwszej z gier (Izrael jako strona konfliktu, w którą wciela się tu użytkownik, ma istotną przewagę wynikającą z mechaniki gry, a w przypadku problemów może poprosić sojuszników o finansowe wsparcie, co czyni wynik rozgrywki niemal jednoznacznie przesądzonym) i wynikająca z niej sugestywność przekazów, ich powszechna dostępność (dystrybucja przez internet) i stosunkowo niewielkie koszty sprawiają, że można spodziewać się, że gry zaangażowane w jeszcze większym stopniu staną się istotnym elementem dyskursu publicznego i znaczącym narzędziem społecznego oddziaływania. Gry takie są jednak również w istotnym stopniu kontrowersyjne (co poniekąd zwiększa ich potencjał w zakresie budowania świadomości) - autor nie porusza tu kwestii ryzyka ewentualnego nieodczytania ironii i pozostania świadomości użytkownika jedynie na poziomie podstawowym (być może w przypadku przywołanych przykładów ironia jest na tyle wyrazista, że ryzyko to jest marginalne), co mogłoby w znaczącym stopniu zniekształcić ostateczny przekaz.
Do niezaprzeczalnych atutów recenzowanej publikacji należy przede wszystkim umiejętne wskazywanie zależności pomiędzy grami wideo a innymi zjawiskami kultury, przy równoczesnym przekonującym zakreślaniu obszarów ich odrębności. Swobodne posługiwanie się kategoriami z zakresu różnych nauk i teorii nie sprawia tu wrażenia metodologicznej niekonsekwencji czy eklektyzmu, a raczej świadomego dostosowania materiału badawczego do złożoności eksplorowanej materii. Niezwykle istotnym elementem wydaje się tu także bogactwo szczegółowo analizowanych przykładów, którym, co bardzo ważne, towarzyszy rozbudowany, szczegółowo i klarownie opisany materiał ilustracyjny (przede wszystkim, choć nie tylko, screeny z gier), pozwalający osobom nieznającym opisywanych zjawisk w znacznie lepszym stopniu je sobie wyobrazić. Kluczową kategorią i zdecydowanie najbardziej frapującym elementem wywodu zdaje się tu emersja i jej konsekwencje dla poetyki gier wideo, aczkolwiek analizy problematyki interfejsów i sygnały w zakresie literatury grywalnej i gier zaangażowanych również stanowią istotny wkład w badania naukowe w tej dziedzinie. Rozstrzygnięcia Kubińskiego to interesująca propozycja aparatu pojęciowego i narzędzi, które wykorzystać można do opisu i badania gier wideo, pozwalające równocześnie zapoznać się z wieloma zjawiskami z zakresu tej dziedziny kultury, poznać jej różnorodność i złożoność i dostrzec jej potencjał zarówno ludyczny, jak i artystyczny oraz publicystyczny. 


\title{
SŁOWA KLUCZOWE:
}

\author{
ludologia
}

\section{ABStrakT:}

W swojej książce Gry wideo. Zarys poetyki Piotr Kubiński umiejętnie zachowuje równowagę pomiędzy porównywaniem szczególnego zjawiska, jakim są gry wideo, do innych sztuk i próbą opisu nowego fenomenu z wykorzystaniem niektórych tradycyjnych kategorii, a podkreślaniem ich znaczącej odrębności oraz cech charakterystycznych. Poszukując adekwatnych narzędzi badania nowego zjawiska, autor wieloaspektowo analizuje rozmaite przykłady, rozpatrując takie kategorie, jak immersja, emersja oraz graficzny interfejs użytkownika. Porusza także problem związków gier wideo z innymi gatunkami sztuki, czyniąc to nie tylko w rozdziale temu poświęconym, ale i w całej publikacji. Egzemplifikację wspiera przejrzystym i interesującym materiałem ilustracyjnym. Książka ta wydaje się istotnym elementem w polskich badaniach nad grami wideo, szczególnie ze względu na wprowadzenie i szczegółowe omówienie pojęcia emersji, ale także ze względu na wnikliwe odczytania konkretnych zabiegów artystycznych i tropów. 


\section{i $\mathrm{m} \mathrm{m} \mathrm{e} \mathrm{j}$ a}

\section{POETYKA GIER WIDEO}

\section{NOTA O AUTORZE:}

Barbara Kulesza-Gulczyńska - od 2013 roku doktorantka w Zakładzie Literatury i Kultury Nowoczesnej na Wydziale Filologii Polskiej i Klasycznej UAM. Absolwentka Międzykierunkowych Indywidualnych Studiów Humanistycznych. Główne zainteresowania badawcze obejmują: literaturę internetu (szczególnie twórczość fanowska), zjawiska związane z przenikaniem się starych i nowych mediów, kulturę popularną oraz działania i funkcjonowanie wspólnot fanowskich. Do najważniejszych publikacji należą artykuły: Zagadnienie autorstwa $w$ utworach fan fiction. Fandom jako kolektyw twórczy, w: Re-miks. Teorie i praktyki, red. M. Gulik, P. Kaucz, L. Onak, Kraków 2011; Znaczenie Internetu $w$ rozwoju fan fiction, czyli twórczość fanowska i nowe media, w: Media - kultura popularna - polityka. Wzajemne oddziaływania i nowe zjawiska, red. J. Bierówka, Kraków 2014 oraz Czym się różni autor od attora, czyli fanowskie gry $z$ autorstwem, „Tekstualia” 2015, nr 2. 